\title{
Queen Mary University London: one of the longest established masters of sport and exercise medicine globally (continuing professional development series)
}

\author{
Simon Lack, ${ }^{1,2}$ Aleksandra Birn-Jeffery, ${ }^{1}$ Ian Beasley, ${ }^{1}$ Dylan Morrissey ${ }^{1}$
}

\begin{abstract}
INSTITUTION
Sports and Exercise Medicine, William Harvey Research Institute, School of Medicine and Dentistry, Queen Mary University London (QMUL), London, UK.
\end{abstract}

\section{COURSE}

Master of Science (MSc) in Sports and Exercise Medicine.

\section{WHY?}

With the continued growth of sports participation, both recreationally and professionally, the expectation for the highest level of health provision is also set to grow. Completion of a Masters in Sports and Exercise Medicine (SEM), to inform evidence-based medicine delivery and demonstrate professional competencies, is increasingly becoming a requirement within these sporting environments. ${ }^{1}$

\section{OVERVIEW}

The SEM Masters programme is open to nationally and internationally qualified medical doctors, physiotherapists, osteopaths and podiatrists (table 1). As the longest established SEM MSc in Europe (and possibly the world), the programme has a prestigious history. The vision of Professor John King, as course founder $>30$ years ago, was to provide the best possible SEM training and to inspire the next generation of SEM expert clinician scientists. Graduates include the Chief Medical Officers for Team Great Britain at the Beijing 2008 and London 2012 Olympic and Paralympic games, and the Greek team at Athens 2004.

${ }^{1}$ Sports and Exercise Medicine, William Harvey Research Institute, School of Medicine and Dentistry, Queen Mary University London, London, UK

${ }^{2}$ Pure Sports Medicine, London, UK

Correspondence to Dr Simon Lack, Sports and Exercise Medicine, Mile End Hospital, Bancroft Road, London E1 4DG, UK; s.lack@qmul.ac.uk
The course was inspirational, with access to world-class experts lecturing, and practical exposure with the top clinicians of the time. This exposure was transformational for me as I moved full-time into sports medicine. (Dr Nick Webbon (1992 Graduate), Chair of the British Paralympic Association)

The learning objectives and course content are aligned with competencies defined by the International Federation of Sports Physiotherapists and the medical Faculty of Sports and Exercise Medicine. All students complete five core modules-three within a multidisciplinary environment and two specific to the professional route (medical, physiotherapy/osteopathy and podiatry) (figure 1). The three multidisciplinary modules focus on core principles of SEM assessment and research methods, forming the majority of the first semester (full-time) or year (part-time) of study. In addition, students complete three optional modules and a research project. Optional modules include Podiatry and Biomechanics, Exercise as a Health Tool, Football Medicine, Dance Medicine, Imaging in Sports Medicine and Military Sports Medicine and Rehabilitation. Students have the option of completing, or not completing, an original research project to exit with a masters in SEM or postgraduate diploma, respectively (figure 1). The postgraduate certificate offered in podiatric sports medicine includes four core modules and clinical experience.

During the MSc, students are expected to accrue 32 (half-day) multidisciplinary, clinical placements (organised by the student in collaboration with programme staff). Unique clinical learning opportunities are provided, including monthly interdisciplinary combined clinics, practical experience of elite sporting environments and development of clinical reasoning within leading sports medicine facilities (eg, Pure Sports Medicine and the Blackberry Clinic).

\begin{tabular}{|c|c|}
\hline Admission criteria & $\begin{array}{l}\text { Qualified medical doctors, physiotherapists, osteopaths or podiatrists with } \geq 1 \text { year } \\
\text { clinical experience } \\
\text { English language proficiency } \\
\text { Relevant CV }\end{array}$ \\
\hline Fees and funding & 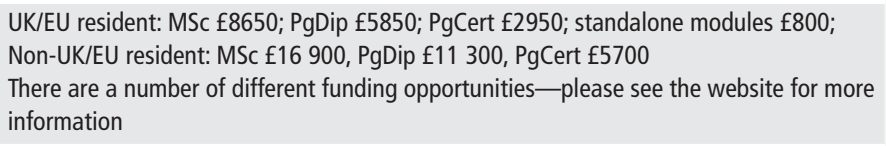 \\
\hline Duration and intensity & $\begin{array}{l}\text { Full-time (MSc): } 1 \text { year } \\
\text { Part-time: PgCert } 1 \text { year; PgDip } 2 \text { years; MSc 2-4years }\end{array}$ \\
\hline Delivery method & $\begin{array}{l}\text { Face-to-face learning at Mile End Campus, QMUL } \\
\text { Clinical visits across the South East of England }\end{array}$ \\
\hline Start dates & September \\
\hline Recommended work load & $\begin{array}{l}\text { Per module ( } 15 \text { credits): } 30 \text { contact hours } \\
\text { Overall: } 120 \text { hours of student effort per } 15 \text { credits } \\
\text { MSc } 180 \text { credits, PGDip } 120 \text { credits, PGCert } 60 \text { credits }\end{array}$ \\
\hline Student feedback & $\begin{array}{l}\text { Course evaluation is completed through the universities central, eight question, } \\
\text { questionnaire, with scores given for each question between } 5 \text { and } 1(5=\text { definitely agree, } \\
\text { 1=definitely disagree). Across all taught modules, answering the question: (1) The } \\
\text { modules are well taught?: mean (SD)=4.2 }(0.6) ;(2) \text { The criteria used in marking on } \\
\text { the module have been made clear in advance?: mean }(S D)=3.7(0.9) ;(3) \text { I have been } \\
\text { given adequate feedback during the module?: mean }(S D)=3.8(0.9) ;(4) \text { I have received } \\
\text { sufficient advice and support with my studies on the module?: mean }(S D)=4(0.8) ;(5) \\
\text { The module is well organised and runs smoothly?: mean }(S D)=4(0.8) ;(6) \text { I had access } \\
\text { to good learning resources for the module?: mean }(S D)=3.9(0.9) ;(7) \text { The use of QMplus } \\
\text { has made an appropriate contribution to this module?: mean }(S D)=4(1) ;(8) \text { Overall I am } \\
\text { satisfied with the quality of the module?: mean }(S D)=4.1(0.8) \text {. } \\
\text { Students testimonials for the course can be found on the website http://www.whri.qmul. } \\
\text { ac.uk/about-us/418-sports-exercise-medicine\#testimonials }\end{array}$ \\
\hline
\end{tabular}


Pathways in Sports and Exercise Medicine:
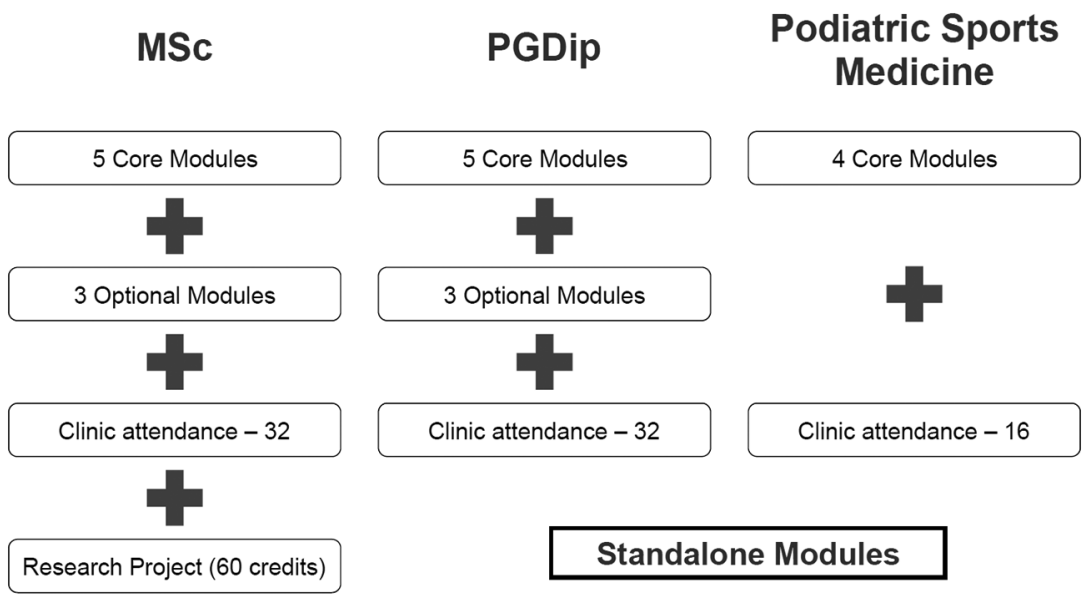

Figure 1 Diagrammatic representation of the flow through the Master of Science, Postgraduate Diploma and Postgraduate Certificate (Podiatric Sports Medicine), plus standalone modules.

Clinical placements are undertaken within London and Home Counties to ensure a diversity of SEM experiences, with international students able to complete appropriate clinical placements in their home countries following discussion with the course leads.

The taught components of the course are delivered in lecture and practical formats across two semesters (semester 1: September-December; semester 2: January-March inclusively). While fulltime students will attend the university for these taught sessions (Tuesdays/ Thursdays) during both semesters, part-time students can choose to study the MSc over 2-4 years. These sessions are presented by national and international experts, from cutting edge basic scientists to physiotherapists (eg, Jon Fern, head physiotherapist, Chelsea FC; Claire Small, Clinical Director, Pure Sports Medicine), doctors (eg, Dr Ritan Mehta, Womens Lead Performance Doctor, The FA) and other health professionals, including psychologists, nutritionists and strength and conditioning coaches working with world-class athletes. Assessments include essays (eg, literature review and case reports) and written/practical exams. The research project is a significant component of the MSc programme, in which students are teamed with mentors specific to the area of research interest. They complete a systematic review, novel research project and presentation of findings at the annual QMUL SEM clinical academic conference. The topic of study is chosen by the student and guided by their mentor, with many students publishing their research in peer-reviewed journals.

The teaching team of 15 substantive and 30 honorary staff, led by Dr Dylan Morrissey - an National Institute of Health Research/Higher Education England Consultant Physiotherapist and Clinical Reader with a long history of working in elite sport-work closely with students to develop clinical excellence in SEM. Overall, the design of the programme provides a comprehensive foundation from which students take forward their own specific and continued professional development in SEM.

\section{APPLICATION DEADLINES}

First of September each year.

\section{LOCATION}

QMUL is one of 24 universities that make up the prestigious Russell Group, which represents the leading research-led universities in the UK. The Centre for SEM teaching facility is situated on the same campus as the sports injury, physiotherapy, podiatry and the interdisciplinary sport clinics within the multicultural and vibrant East End of London, Mile End.

\section{FURTHER INFORMATION}

MSc Course Lead: Dr Simon Lack-s. lack@qmul.ac.uk

MSc Course Administrator: Sue Tracey - s. tracey@qmul.ac.uk

W: http://www.whri.qmul.ac.uk/about-us/ 418-sports-exercise-medicine

Twitter:@QMUL@simonthephysio@ DrDylanM

Acknowledgements The particular role of Professor John King, Dr David Perry, Dr Nat Padhiar and Dr Zoe Hudson in setting up and developing the course at various stages is fully acknowledged, as is the contribution of the staff, visiting lectures, honorary staff and our wide community of alumni and colleagues without whom the course would not be the success that it consistently is.

Competing interests None declared.

Provenance and peer review Not commissioned; externally peer reviewed.

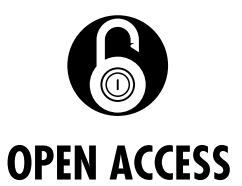

Open Access This is an Open Access article distributed in accordance with the Creative Commons Attribution Non Commercial (CC BY-NC 4.0) license, which permits others to distribute, remix, adapt, build upon this work non-commercially, and license their derivative works on different terms, provided the original work is properly cited and the use is noncommercial. See: http://creativecommons.org/licenses/ by-nc/4.0/

(C) Article author(s) (or their employer(s) unless otherwise stated in the text of the article) 2018. All rights reserved. No commercial use is permitted unless otherwise expressly granted.

$$
\text { A Check for updates }
$$

To cite Lack S, Birn-Jeffery A, Beasley I, et al. Br J Sports Med 2018;52:206-207.

Accepted 26 July 2017

Br J Sports Med 2018:52:206-207. doi:10.1136/bjsports-2017-098108

\section{REFERENCE}

1 Culvenor AG. Professional pathways towards excellence in sports physiotherapy: opportunities and barriers. $\mathrm{Br} J$ Sports Med 2017;51:415-6. 